\author{
М. РАЙЛИ ${ }^{1}$ \\ Т. ПРЕНЦЛЕР \\ ${ }^{1}$ Университет Саншайн-Кост, г. Сиппи Даунс, Австралия

\section{СОГААСИТЕАЬНЫЕ ПРОЦЕАУРЫ ИАИ МЕАИАЦИЯ: РАБОТА С ЖАЛОБАМИ НА АЕЙСТВИЯ ПОЛИЦИИ В АВСТРАЛИЙСКОМ ШТАТЕ КВИНСАЕНА}

Контактное лицьо:

Мэри Райли, магистр криминологии и уголовного правосудия, преподаватель Школы права и криминологии, Университет Саншайн-Кост

Адрес: ул. Сиппи Даунс Драйв, 90, Квинсленд, 4556, Австралия

E-mail: MBaker1@usc.edu.au

Тимоти Пренцлер, профессор в области криминологии и правосудия Школы права и криминологии, Университет Саншайн-Кост

Адрес: ул. Сиппи Даунс Драйв, 90, Квинсленд, 4556, Австралия

Цель: анализ работы с жалобами на действия сотрудников полиции в австралийском штате Квинсленд.

Методы: диалектический подход к познанию социальных явлений, позволяющий проанализировать их в историческом развитии и функционировании в контексте совокупности объективных и субъективных факторов, который определил выбор следующих методов исследования: формально-логический, сравнительно-правовой и социологический.

Результаты: начиная с 1990-х гг. в Австралии разрабатываются и внедряются различные программы для работы с жалобами граждан на действия полиции, например, согласительные процедуры. Полиция Квинсленда проявляет большую активность в развитии собственных программ медиации в сотрудничестве с надзорными органами. Однако, несмотря на неоднократные положительные результаты, здесь по-прежнему неохотно используют медиацию, предпочитая неформальное разрешение конфликтов с помощью управленческого подхода (согласительные процедуры). При этом правоохранительные органы проводят расследование внутри своих подразделений, а участие заявителя ограничено, как и возможность очной встречи с сотрудником, на которого подана жалоба. Между тем в научной литературе отмечаются положительные стороны медиации, особенно принципов реституционного правосудия, так как при этом стороны вступают в диалог и могут вынести из него что-то полезное. Такой подход более эффективен и лучше отвечает потребности заявителей в системе работы с жалобами, основанной на принципах вовлеченности и беспристрастности; при этом информация, полученная в результате работ с такими заявлениями, может использоваться с целью совершенствования правоохранительной деятельности. Работа с жалобами в режиме медиации доступна по запросу в полиции Квинсленда, однако она не нашла широкого распространения.

Научная новизна: в данной статье представлен исторический обзор применения медиации и согласительных процедур в системе работы с жалобами в полиции Квинсленда. Авторы отвечают на вопрос, почему согласительные процедуры получили распространение, тогда как медиация в основном продолжает оставаться в тени. В работе используется качественный анализ открытой документации и полуструктурированных интервью с основными действующими лицами. Результаты показывают, что пилотный проект 1992 г. по медиации был очень успешным. Однако согласительные процедуры получили приоритет в полиции Квинсленда из-за дешевизны, а также, как было

Впервые статья опубликована на английском языке в журнале Criminology, Criminal Justice, Law \& Society and The Western Society of Criminology Hosting by Scholastica. По вопросам коммерческого использования обратитесь в редакцию журнала Сriminology, Criminal Justice, Law \& Society (CCJLS) и The Western Society of Criminology: CCJLS@WesternCriminology.org.

Цитирование оригинала статьи на английском: Riley M., Prenzler T. Conciliation Versus Mediation of Complaints Against Police: Lessons from the Queensland Experience, Criminology, Criminal Justice, Law \& Society, 2020, Vol. 21, No. 1, pp. $22-38$.

URL публикации: https://ccils.scholasticaha.com/article/12468.ndf

Райли М., Пренщлер Т. Согласительные процедуры или медиация: работа с жалобами на действия полиции в австралийском штате Квинсленд Riley M., Prenzler T. Conciliation Versus Mediation of Complaints Against Police: Lessons from the Queensland Experience 
заявлено, лучшей согласованности с мерами по совершенствованию системы управления. Спустя три десятилетия эти преимущества не подтвердились, тогда как медиация, по научным данным, должна являться ключевым компонентом системы работы с жалобами и поддержания дисциплины в полиции.

Практическая значимость: основные положения и выводы статьи могут быть использованы в научной, педагогической и правоприменительной деятельности при рассмотрении вопросов, связанных с жалобами граждан на действия сотрудников правоохранительных органов.

Ключевые слова: неформальное разрешение конфликта; согласительные процедуры; медиация; полиция; жалобы; реституционное правосудие

Благодарность: авторы выражают благодарность отделению полиции Квинсленда за помощь и поддержку в проведении данного исследования.

Замечание: мнения, выраженные в данной статье, не обязательно отражают точку зрения отделения полиции Квинсленда; любые ошибки и неточности являются зоной ответственности авторов статьи.

Статья находится в открытом доступе в соответствии с Creative Commons Attribution Non-Commercial License (http://creativecommons. org/licenses/by-nc/4.0/), предусматривающем некоммерческое использование, распространение и воспроизводство на любом носителе при условии упоминания оригинала статьи.

Как цитировать русскоязычную версию статьи: Райли М., Пренцлер Т. Согласительные процедуры или медиация: работа с жалобами на действия полиции в австралийском штате Квинсленд // Актуальные проблемы экономики и права. 2020. Т. 14, № 4. С. 870-890. DOI: http://dx.doi.org/10.21202/1993-047X.14.2020.4.870-890

The scientific article

\author{
M. RILEY ${ }^{1}$, \\ T. PRENZLER ${ }^{1}$ \\ ${ }^{1}$ USC, Sippy Downs, Australia
}

\title{
CONCILIATION VERSUS MEDIATION OF COMPLAINTS AGAINST POLICE: LESSONS FROM THE QUEENSLAND EXPERIENCE
}

\section{Contact:}

Mary Riley, Lecturer in the School of Law and Criminology, USC

Address: USC Australia, 90 Sippy Downs Drive, Sippy Downs, Queensland, 4556, Australia E-mail: MBaker1@usc.edu.au

Timothy Prenzler, Professor of Criminology \& Justice in the School of Law and Criminology, USC

Address: USC Australia, 90 Sippy Downs Drive, Sippy Downs, Queensland, 4556, Australia

Objective: to analyze the dispute resolution practices for dealing with citizen-initiated complaints against police in Queensland, Australia.

Methods: dialectical approach to cognition of social phenomena, allowing to analyze them in historical development and functioning in the context of the totality of objective and subjective factors, which predetermined the choice of the following research methods: formal-logical, comparative-legal, and sociological.

The article was first published in English language by Criminology, Criminal Justice, Law \& Society and The Western Society of Criminology Hosting by Scholastica. For more information please contact: CCJLS@WesternCriminology.org.

For original publication: Riley M., Prenzler T. Conciliation Versus Mediation of Complaints Against Police: Lessons from the Queensland Experience, Criminology, Criminal Justice, Law \& Society, 2020, Vol. 21, No. 1, pp. 22-38.

Publication URL: https://ccils.scholasticahq.com/article/12468.pdf

Райли М., Пренилер Т. Согласительные процедуры или медиация: работа с жалобами на действия полиции в австралийском штате Квинсленд Riley M., Prenzler T. Conciliation Versus Mediation of Complaints Against Police: Lessons from the Queensland Experience 
Results: since the 1990s, alternative dispute resolution practices for dealing with citizen-initiated complaints against police, such as conciliation, have progressively been trialed and implemented in police services across Australia. The Queensland Police Service was one of the most proactive services in trialing independently facilitated complaints mediation programs in collaboration with its oversight agency. However, despite repeated positive outcomes, the Service refrained from actively using mediation, preferring instead to use management dominated informal resolution (conciliation). This process, characterized by police investigating police, continues to limit complainant participation by denying them the opportunity to meet faceto-face with the subject officer. Yet the literature cites mediation, especially practices based on restorative principles as beneficial because it brings disputing parties together in dialogue that is educative for both parties, reparatory, and better satisfies complainants' aspirations for an inclusive and neutral complaints system, while data from mediated complaints can also be used to inform police conduct improvement strategies. Complaints mediation is available upon request within the Queensland Police Service, however, it is not widely promoted, and is internally facilitated.

Scientific novelty: this article presents an historical account of the application of mediation and conciliation to the Queensland Police Service complaints system. The authors answer the question why conciliation has become the default approach and mediation continues to be largely ignored. This is done through a qualitative analysis of publicly available documents and semi-structured interviews with key stakeholders. The findings reveal that the 1992 Mediation Pilot was very successful. However, the Queensland Police Service adopted conciliation because it was cheaper and, they claim, better aligned with managing behavioral improvements. Three decades on, there has been little evidence of this, while the literature clearly shows that mediation should be a key component of any police complaints and discipline system. The findings reveal that the 1992 Mediation Pilot was very successful. However, the Queensland Police Service adopted conciliation because it was cheaper and, they claim, better aligned with managing behavioral improvements. Three decades on, there has been little evidence of this, while the literature clearly shows that mediation should be a key component of any police complaints and discipline system.

Practical significance: the main provisions and conclusions of the article can be used in scientific, pedagogical and law enforcement activities when considering issues related to the citizens' claims on the actions of law enforcers.

Keywords: Informal resolution of conflict; Conciliation procedures; Mediation; Police; Claims; Restoration justice

Acknowledgements: the authors wish to acknowledge the support and assistance from the Queensland Police Service in undertaking this research.

Disclaimer: the views expressed in this publication are not necessarily those of the Queensland Police Service and any errors of omission or commission are the responsibility of the authors.

The article is in Open Access in compliance with Creative Commons Attribution Non-Commercial License (http://creativecommons.org/licenses/by-nc/4.0/), stipulating non-commercial use, distribution and reproduction on any media, on condition of mentioning the article original.

For citation of Russian version: Riley M., Prenzler T. Conciliation Versus Mediation of Complaints Against Police: Lessons from the Queensland Experience, Actual Problems of Economics and Law, 2020, Vol. 14, No. 4, pp. 870-890. DOI: http:// dx.doi.org/10.21202/1993-047X.14.2020.4.870-890

Начиная с 1990-х гг. по всей Австралии разрабатывались и внедрялись различные программы для работы с жалобами граждан на действия полиции [1, 2]. Система внутренних расследований по заявлениям граждан подверглась тщательному изучению в связи с несколькими громкими делами, в частности, дел Вуда (Wood) и Фитцджеральда (Fitzgerald). В результате был сделан вывод, что необходимо реформировать систему внутренних расследований для обеспечения законности и справедливости по отношению к за- явителям [1]. В то же время в системе гражданского и уголовного правосудия развернулось движение за развитие согласительных процедур и медиации как средств открытого диалога между полицией и заявителями. Неформальные способы разрешения конфликтов, т. е. посредничество внутри отдела полиции при улаживании споров между гражданскими заявителями и сотрудниками полиции, в той или иной степени заменили традиционные процедуры урегулирования $[3,4]$; заявители получили более активную, 
хотя и ограниченную, роль в процедурах и результатах таких дел. Медиация, обычно понимаемая как процесс сближения сторон в рамках управляемого диалога с целью достижения обоюдно приемлемого решения, также получила стимул к развитию в международных полицейских юрисдикциях в качестве инструмента разрешения мелких конфликтов для удовлетворения обеих сторон, основанного на принципах вовлеченности и совещательности [5].

Полиция Квинсленда проявляла самую большую активность среди всех отделений полиции Австралии в развитии инновационных подходов к разрешению конфликтов, в частности, медиации, стремясь улучшить свою работу в сообществе [2]. Однако, несмотря на успех пилотных проектов и неоднократное подтверждение эффективности медиации при работе с жалобами [6, 5, 7], полиция Квинсленда (как и другие отделения полиции Австралии) воздерживается от активного использования этого метода, отдавая предпочтение внутренним согласительным процедурам, например, методу неформального разрешения мелких конфликтов. Возможно, это происходит благодаря убеждению, что полиция, в отличие от штатских структур, обладает достаточным набором компетенций - знанием законов и соответствующих процедур - для самостоятельной работы с жалобами [8]. Однако изучение ситуации начиная с 1990-х гг. показывает, что число жалоб остается высоким по всей стране [9], в том числе в Квинсленде. Это говорит о том, что для многих примирительные меры являются неудовлетворительными. Согласно исследованиям, заявители предпочитают процедуру очной медиации [10], так как прямое общение убеждает их, что заявление принимается всерьез, процесс идет без дискриминации, а они сами принимают значимое участие в принятии решения по их жалобе.

Цель настоящего исследования - провести тщательный анализ политики и практики медиации жалоб граждан на действия сотрудников полиции в системе по работе с жалобами полиции Квинсленда. Исследуемый период - с 1989 г. (после реформ, проведенных в результате дела Фитцджеральда) до настоящего времени.

Расследование по делу Фитцджеральда началось в ответ на заявления общественности о должностных преступлениях и коррупции в полиции [11]. Было установлено, что работа отдела внутренних расследований полиции Квинсленда была «некомпетентной, неэффективной и в значительной степени пристрастной в пользу полицейских» [12, p. 82], а деятельность полицейского арбитражного суда опиралась на неадекватные механизмы при разборе дел о должностных преступлениях и коррупции. В результате упомянутые органы были ликвидированы [12], а меры по восстановлению доверия к полиции были сконцентрированы на работе в сообществе [10]. Был учрежден орган надзора над деятельностью полиции - комиссия по уголовному правосудию. Однако спустя десять лет отмечалось, что выводы по делу Фитцджеральда «так никогда и не были внедрены в практику на местном уровне, и прежняя модель внутренних расследований остается доминирующей» $[10$, p. 576]. Эта ситуация продолжается и сегодня; однако причины этого до сих пор не ясны. Поэтому в данной работе ставится задача выяснить, почему медиация не используется вместо согласительных процедур, что препятствует привлечению гражданских лиц к работе с жалобами, и каковы в целом пути совершенствования деятельности полиции Квинсленда и других отделов полиции.

\section{Обзор литературы}

Легитимность системы работы с жалобами на действия полиции основывается на ее объективности, процедурной строгости и справедливости $[13,14]$. Эти черты могут проявляться не в полной мере, если система находится под внутренним управлением и применяет конкурентный подход. Как правило, системы работы с жалобами нацелены на усиление дисциплины среди сотрудников полиции, а их деятельность осложнена за счет множества перекрывающих друг друга уровней лиц, принимающих решения, включая отделы внутренних расследований, командный состав и непосредственных руководителей $[15,16]$. Эта запутанная система часто лишает гражданских заявителей возможности участвовать в разрешении их проблем и убеждает, что жаловаться бесполезно [17]. Однако жалобы - это важный показатель того, насколько хорошо работает служба и в чем можно улучшить ее работу. Громкие случаи коррупции в полиции, смерти гражданских лиц в местах лишения свободы, движения за гражданские права, создание гражданских надзорных органов все это подчеркивает необходимость большей про- 
зрачности, независимости и участия гражданского населения в процессах рассмотрения жалоб на действия полиции.

С самого начала движения за альтернативные способы разрешения конфликтов в 1990-е гг. в ответ на требования заявителей об их большей вовлеченности в процесс принятия решений по жалобам [18, 19] программы медиации были опробованы и внедрены во многих странах. В работе Walker и соавт. [20] были исследованы 16 программ медиации по заявлениям гражданских лиц в США. Было показано, что независимая процедура медиации создает безопасную среду, позволяющую добиться взаимопонимания сторон и потенциально разрешения конфликта. Кроме того, затраты на процедуру медиации примерно вполовину меньше таковых на согласительные процедуры, проводимые полицией. В работе были также определены проблемы при внедрении программ медиации, включая нежелание сторон участвовать в них, дисбаланс власти, навыки медиаторов, вопросы конфиденциальности. Однако указанные проблемы были в основном отнесены на счет ограниченного понимания процедуры медиации. В целом авторы пришли к выводу, что медиация является «многообещающей альтернативой» для работы с жалобами и несет в себе потенциальные преимущества как заявителям, как и правоохранительным органам, например, совершенствование подотчетности полиции и улучшение взаимоотношений с местным сообществом [20, p. 91]. Три исследования в Великобритании $[21,8,22]$ рассматривали преимущества медиации перед другими способами разрешения споров между заявителями и сотрудниками полиции. Результаты свидетельствуют, что заявители искренне сожалели о возникновении конфликтов и выражали это отношение на очных встречах. В качестве основных причин конфликта назывались «желание прояснить ситуацию и получить объяснение» и «услышать извинение» [8, p. 16]. Заявители не желали строгих санкций против полицейских, но хотели, чтобы такое поведение не повторялось в будущем.

В трех работах $[6,5,7]$, которые будут описаны ниже, оценивалась эффективность внедренных программ медиации; было подтверждено положительное отношение заявителей к процедуре медиации. В 2005 г. проводилась оценка программы медиации в отделе по работе с жалобами полиции г. Нью-
Йорка; было показано, что заявители, проходившие процедуру медиации $(n=16)$, в большей степени удовлетворены результатом, чем проходившие процедуру полного расследования $(n=19): 81 \%$ против $32 \%$ соответственно. При этом процедура медиации включала возможность очной встречи сторон, выступления при разборе жалобы, а также обсуждения предмета спора с независимым медиатором в конфиденциальной обстановке [6]. Офицеры полиции, участвовавшие в процедуре медиации $(n=15)$, были в особенности довольны (67 \%) возможностью выступления при разборе жалобы.

Исследование, проводившееся в 2005 г. в двух полицейских участках в Англии, было посвящено сравнению программы медиации, основанной на принципах реституционного правосудия и внедренной на участке Долины Темзы, с процедурой неформального разрешения споров, применявшейся в отделе полиции Гемпшира. Первый подход показал более высокий уровень удовлетворенности как заявителей (61\% против $33 \%)$, так и полицейских (85\% против 69 \%). В качестве положительных моментов респонденты отмечали способ организации открытого общения между сторонами, обеспечение медиаторами уважительного обращения друг к другу и равного количества времени для высказываний.

В работе Young и соавт. было проведено 47 процедур очной медиации, из которых 22 закончились успешно. Еще 19 конфликтов были разрешены с помощью фасилитатора - специалиста по реституционному правосудию, который «брал на себя роль посредника между сторонами» [7, р. 291]. Фасилитаторы были специально подготовлены; они могли быть или не быть сотрудниками полиции. Заявители были довольны возможностью «выразить свои эмоции, услышать мнение другой стороны и прийти к взаимопониманию» [7, р. 298]. В пользу медиации говорят и негативные аспекты процедуры неформального разрешения споров. Young и соавт. обнаружили, что участники этой процедуры в отделе полиции Гемпшира были не удовлетворены «отсутствием прозрачности относительно того, что именно говорил сотрудник, проводивший процедуру, полицейскому, на которого поступила жалоба (был ли это действительно «выговор»)» [7, р. 302]; они считали, что при стандартной процедуре неформального разрешения споров «любое признание некорректного поведения сводится к нулю, 
если информация не поступает обратно к заявителю» [7, p. 304]

В 2012 г. проводилась оценка программы медиации в отделе по работе с жалобами полиции Денвера; было обнаружено, что начиная с внедрения этой программы в 2005 г. уровень удовлетворенности процессом разрешения конфликтов стабильно возрастал как среди заявителей, так и среди сотрудников полиции [23]. 96 \% респондентов были согласны, что медиация, проводимая независимым специалистом, «позволила им объяснить свою позицию» [23, p. 23]. $85 \%$ заявителей и $87 \%$ полицейских считали, что медиация «либо достаточно эффективно, либо очень эффективно помогает им понять действия другой стороны» [23, p. 23]. Среди иных преимуществ называлось снижение уровня предвзятости при участии нейтральной стороны, снижение финансовых затрат и уменьшение времени на разрешение конфликтов по сравнению с формальной процедурой расследования. С помощью процедуры медиации были успешно разрешены самые разные жалобы, от грубого поведения и злоупотребления применением силы до расовой предвзятости; это доказывает, что медиация может быть полезна не только при урегулировании мелких конфликтов.

Аналогичным образом, в отчете за 2015 г. о программе медиации в Новом Орлеане, где она на тот момент действовала в течение одного года, сообщается, что все заявители и сотрудники полиции, участвовавшие в 22 процедурах медиации, считают их непредвзятыми. $92 \%$ сотрудников полиции признали медиацию «хорошим способом разрешения споров между гражданскими и полицейскими», и все $100 \%$ сообщили, что согласятся на процедуру медиации в будущем, если на них поступит жалоба [24].

Результаты вышеперечисленных исследований показывают, что заявители хотели бы сообщать о своих претензиях напрямую сотруднику(кам) полиции, участвовавшему(им) в конфликте, и предпочли бы делать это в присутствии нейтральной третьей стороны. И как минимум они хотели бы иметь возможность выбирать, как именно будет разрешен их спор.

В Европе правоохранительные органы также внедряют участие гражданских лиц в процедуру разрешения конфликтов. В большинстве стран существуют надзорные органы, работающие непосредственно с отделами полиции, но с очень ограниченным уча- стием граждан. В Дании недоверие общественности к полицейской системе работы с жалобами привело к созданию в 2011 г. Независимой службы по работе с жалобами на действия полиции. По мнению общественности, существовавшая система действовала в интересах полиции, что косвенно подтверждалось низкими показателями удовлетворения жалоб (например, в 2008 г. -0 \%, в 2016 г. $-6 \%$ ) и ростом недовольства заявителей результатами разбирательств (c $58 \%$ в 2008 г. до $74 \%$ в 2016 г.) [25].

В одном из недавних исследований проводилась оценка деятельности Независимой службы по работе с жалобами; изучалась степень удовлетворенности работой с жалобами и доверия к новой независимой системе. Исследователи связывались с заявителями, чьи жалобы были рассмотрены в период с августа 2014 г. по март 2016 г. ( $N=1$ 597); 658 человек были проинтервьюированы. Результаты во многом совпали с результатами других вышеупомянутых исследований. Заявители выражали недовольство системой, так как считали, что расследования проводятся не независимо от полиции и направлены в основном на поиски доказательств вины полицейского. Большинство заявителей (57 \%) предпочли бы видеть такие действия полиции, которые предотвратили повторение таких ситуаций в будущем (например, грубое обращение сотрудников полиции с гражданами, использование ругательств). 47 \% заявителей хотели бы, чтобы организация признала факт нарушения, а 43 \% считают, что их жалоба не было воспринята серьезно, и хотели бы, чтобы в полиции признали их правоту.

В полиции Дании при работе с гражданскими лицами используют систему неформального разрешения конфликтов. Однако современные исследования показывают, что, по мнению многих заявителей, их жалобы рассматривались Независимой службой. Как считает Holmberg, «некоторые респонденты могли участвовать в процедуре неформального разрешения конфликтов, не понимая этого» $[25$, p. 8$]$. Это может быть связано с тем, что система менялась несколько раз начиная с 2007 г., гражданам предоставляется очень ограниченный объем информации. Медиация была признана наилучшим подходом к работе с жалобами, как и организация Независимой службы по работе с жалобами граждан на действия полиции [25]. Однако при этом возникают два препятствия: во-первых, заявители по-прежнему могут подать 
формальную жалобу, если результат медиации их не удовлетворит; во-вторых, при проведении процедуры медиации полицейские не могут рассчитывать на конфиденциальность, которая предотвратила бы дисциплинарные меры против них. Если бы эти препятствия были устранены до организации Независимой службы, медиация получила бы большее распространение [25]. Тем не менее указанное исследование подтверждает результаты других работ, что заявители стремятся получить признание фактов и возможность узнать точку зрения полиции на нарушения.

\section{Методология}

В настоящей работе использован двухступенчатый качественный подход. Он состоит, во-первых, из контент-анализа общедоступных и конфиденциальных документов и, во-вторых, анализа полуструктурированных интервью с основными информантами. Эти методы применялись последовательно, хотя некоторые документы стали доступны лишь во время проведения интервью. Информация, полученная во время первоначального анализа документации, послужила основой для разработки дальнейших этапов исследования, в том числе выбора основных организаций и лиц для проведения интервью.

Ниже представлены краткие демографические данные, показывающие особенности работы полиции Квинсленда.

\section{Демографические данные места исследования}

В период запуска пилотной программы медиации в 1992 г. в полиции Квинсленда насчитывалось около 5500 штатных сотрудников [26, p. 58], которые обслуживали территорию с населением 3,6 миллиона человек [27]. В течение этого года поступило 319 жалоб на действия полиции [28, p. 26]. При этом пилотная программа медиации была сосредоточена в регионе Брисбен (включая районы Брисбен и Юго-Восточный Квинсленд), где и тогда, и сейчас проживает значительная доля населения штата (в настоящее время 3,6 миллиона человек) [29].

В настоящее время в полиции Квинсленда работает около 15000 штатных сотрудников [30, p. 6.3], обслуживающих территорию с населением 5,1 миллиона человек [29] и площадью около 1,729 миллиона квадратных километров [31], которая по- делена на пять полицейских округов, в свою очередь состоящих из районов [32, p. 21]. В составе населения $49 \%$ - женщины, 51 \% - мужчины, около одной пятой (1 миллион) - граждане, родившиеся за пределами страны, и 4 \% - представители коренных народов [29]. На обширных территориях штата Квинсленд работа полиции по-прежнему затруднена, тем более что разные районы имеют различные потребности. В течение 2019 г. количество жалоб составило 9,5 на 100 штатных (оперативных) сотрудников [32, p. 27], однако следует учитывать, что полицейские ежедневно взаимодействуют с миллионами граждан без жалоб и заявлений [32, р. 79].

\section{Двухступенчатый качественный подход}

В работе использовались данные отчетов с сайта отделения полиции Квинсленда: ежегодные отчеты с 2010 по 2018 г. (более ранние отчеты недоступны) и документация по работе с жалобами и стратегическому планированию за период 2014-2018 гг. Использовались следующие данные отчетов с сайта Комиссии по уголовному правосудию: ежегодные отчеты с 1991 по 2003 г. и отчеты о ходе неформального разбирательства за период с 1994 по 1996 г. С сайта Министерства юстиции и генеральной прокуратуры были получены ежегодные отчеты с 2012 по 2018 г. Кроме того, мы использовали Отчет по пилотному проекту медиации жалоб против полиции за 1992 г. Для создания общей картины и уточнения деталей мы также изучили множество первичных источников, таких как протоколы допросов, и источников, специфичных для Квинсленда, в том числе рассмотренные в обзоре [18-20,7]. Использовался также метод поиска по ключевым словам, таким как «жалобы», «полиция», «гражданское лицо», «альтернативные методы разрешения конфликтов», «медиация», «восстановительное правосудие», «неформальное разбирательство», «разрешение конфликтов на местах».

Все учреждения Квинсленда, задействованные в работе с конфликтными ситуациями, согласились предоставить своих сотрудников для интервью. Всего с июня 2018 г. по июнь 2019 г. было проведено двенадцать полуструктурированных интервью, из них шесть интервью с основными опрошенными бывшими и действующими сотрудниками отделения полиции Квинсленда (интервью 1-6) [33, 34]; с членами Комиссии по преступности и коррупции (ранее - 
Комиссия по уголовному правосудию и Комиссия по преступности и должностным правонарушениям; интервью 7-9) [35]; с сотрудниками отдела по работе с конфликтами Министерства юстиции и генеральной прокуратуры (интервью 10-12) [36, 37]. Продолжительность интервью составляла от одного до двух часов. В штаб-квартире Брисбена была проведена также групповая беседа с сотрудниками отделения полиции Квинсленда в присутствии инспектора отдела интеграции и эффективности и трех полицейских - представителей отделов по работе с жалобами и поддержанием дисциплины. Отдельные интервью были проведены с отставными: офицером полиции Квинсленда, членом Отдела по расследованиям и координации Комиссии по уголовному правосудию, которые предоставили информацию о причинах изменений в работе с жалобами, и двумя членами отдела по работе с конфликтами Министерства юстиции и генеральной прокуратуры о роли этого отдела в осуществлении пилотных проектов по медиации. Также состоялось общение по телефону и электронной почте с двумя отставными и двумя действующими членами Комиссии по преступности и коррупции и одним отставным полицейским из другого штата, который имел информацию о процессе внедрения методов неформального разрешения конфликтов и медиации в отделение полиции Квинсленда.

Учитывая небольшое количество участников, авторы признают, что высказанные мнения могут не быть репрезентативными для данного и других отделений полиции.

Формат полуструктурированных интервью был использован для того, чтобы каждое интервью имело определенную базовую структуру, в то же время оставаясь гибким. Предварительные вопросы были разработаны в результате работы с документацией (1-й этап исследования) и касались аргументов за и против применения медиации. Исследование было одобрено Комитетом по науке отделения полиции Квинсленда. Вопросы были сформулированы таким образом, чтобы выявить индивидуальные и групповые ожидания, раскрыть опыт использования альтернативных способов разрешения конфликтов и определить барьеры применения медиации в организации. Вопросы затрагивали пилотную программу медиации и последовавшие за ней изменения в системе работы с жалобами, например:
1. На сайте отделения полиции Квинсленда указана возможность проведения процедуры медиации. Как часто она используется?

2. Проводится ли медиация независимым лицом? Если нет, то почему?

3. Если медиация не применялась в конкретном случае, то по каким причинам?

Данный метод сбора информации имеет свои ограничения, такие как недоступность информации, забывание фактов некоторыми информантами, а также потенциальное влияние групповой беседы на отдельных участников. Кроме того, в исследовании не проводилось бесед с заявителями. Однако богатая практика офицеров полиции, знания и опыт всех опрошенных дали возможность глубоко изучить функционирование системы работы с жалобами с институциональной точки зрения. Использование документальных источников и информации интервью позволило создать общую базу данных.

\section{Результаты 1: документальные источники}

Анализ данных позволил очертить и понять эволюцию системы работы с жалобами отделения полиции Квинсленда. Эта система прошла путь от традиционного состязательного дисциплинарного подхода в конце 1980-х через пилотные проекты в области медиации и согласительных процедур до недавнего подхода под названием «управление разрешением конфликтов на местах».

\section{Традиционная система работы с жалобами в отделении полиции Квинсленда}

До расследования по делу Фитцджеральда все жалобы граждан обрабатывались в рамках длительной и непрозрачной процедуры внутренних расследований. Однако дело Фитцджеральда выявило, что службы внутренних расследований «не имели стандартных рабочих процедур», а полицейский трибунал по работе с жалобами не обладал судебными полномочиями и был «полностью зависим от того учреждения, в котором должен был проводить расследование» [12, pp. 288, 290]. Заявителей допрашивали, заставляли изменить или отозвать жалобы; доля подтвержденных заявлений колебалась около 2 \%. Было рекомендовано полностью реформировать систему, включая введение независимого гражданского надзорного органа. 
Хотя в отчете по делу Фитцджеральда не говорилось конкретно о медиации, было рекомендовано провести программу «огражданствления», когда должности, не требующие навыков полицейской работы, занимают гражданские лица с соответствующей подготовкой.

\section{Комиссия по уголовному правосудию}

Организация в 1989 г. постоянно действующего органа - Комиссии по уголовному правосудию - привела к усилению элемента независимости в модели интегрированного управления отделения полиции Квинсленда [10]. Основной зоной ответственности Комиссии стал надзор за деятельностью полиции, включая реформирование системы работы с жалобами. Комиссия также отвечала за расследование подозрений в «превышении служебных полномочий» (серьезное нарушение, способное привести к увольнению или судебному преследованию) и «неверных действий полиции» (неподобающее поведение по определению Закона об исполнении полицейской службы $^{1}$ [12] и имела полномочия выбирать дела для расследования [38]. В рамках Комиссии действовало также особое подразделение, отвечавшее за расследование мелких заявлений и разрабатывавшее рекомендации для полиции, направленные на уменьшение количества жалоб [28].

\section{Пилотный проект по медиации}

Идея пилотного проекта по медиации возникла в результате положительного опыта вновь созданной Комиссии по уголовному правосудию в работе с жалобами. Этот опыт заключался в организации в 1991 г. встреч полицейских в штатском и гражданских лиц [39]. Комиссия пришла к выводу, что непонимание и реакция обеих сторон, приведшие к конфликту, будут наилучшим образом урегулированы через альтернативную процедуру. Эта инновационная мера привела к созданию программы «Правосудие на местах» на уровне правительства штата (Community Justice Program), направленной на медиацию между членами семей и соседями. Именно тогда медиация в Австралии была официально использована для разрешения конфликтов между гражданами и полицией.

Police Service Administration Act 1990. URL: https://www. legislation.qld.gov.au/view/pdf/inforce/2016-07-01/act-1990-004
Медиация таких «сложных и эмоционально насыщенных споров» приводила к «эффективному и удовлетворительному соглашению между всеми сторонами», включая принесение извинений заявителям [39, p. 1].

Успех применения медиации и изучение зарубежного опыта альтернативных процедур работы с жалобами, проведенные Комиссией, привели к разработке и внедрению пилотного проекта по медиации в сотрудничестве с программой «Правосудие на местах» и отделом полиции. В 1992 г. была запущена шестимесячная программа по работе с мелкими заявлениями, например, о неподобающем поведении, угрозах, недостаточной помощи.

В рамках пилотного проекта независимыми квалифицированными медиаторами было проведено 33 процедуры, в 32 из которых было достигнуто соглашение [38]. На рассмотрение передавалось по четыре дела в месяц, однако в течение пятого месяца было передано 31 дело. Причиной такого всплеска была признана «надежность и эффективность» программы [39, р. 11]. Были выявлены определенные незначительные проблемы, например, трудности при контактах с полицейскими и консультирование медиаторов по деталям дел.

В конце проекта участников опрашивали по поводу их удовлетворенности результатами; всего были получены отклики от 21 заявителя и 19 полицейских. 99 \% заявителей положительно оценили возможность обсудить их точку зрения, а 80 \% сообщили, что медиация является лучшим способом работы с жалобами. Отмечалось, что этот способ быстрее, эффективнее, дешевле, чем формальное расследование, и является более приемлемым для заявителей. Аналогично 79\% полицейских ответили положительно на вопросы об обсуждении их точек зрения и выразили свое предпочтение медиации перед существующими практиками. В шести случаях обе стороны «подписали письменные предложения для комиссара полиции по внесению изменений в процедуры деятельности полиции» [39, p. 24]. По результатам проекта было рекомендовано ввести медиацию во всех областях, где действовала программа «Правосудие на местах».

Несмотря на успех пилотного проекта, целесообразность медиации позже подвергалась сомнению по финансовым, логистическим, процедурным основаниям и соображениям конфиденциальности $[40,11]$. Программа «Правосудие на местах», в рамках

Райли М., Пренилер Т. Согласительные процчедуры или медиация: работа с жалобами на действия полищии в австралийском итате Квинсленд Riley M., Prenzler T. Conciliation Versus Mediation of Complaints Against Police: Lessons from the Queensland Experience 
которой финансировался проект, была недостаточно обеспечена кадрами, чтобы вести проекты по всему штату Квинсленд, а отделение полиции не имело достаточного финансирования [40]. Кроме того, конфиденциальность процедуры медиации предполагала, что ни полиция, ни программа «Правосудие на местах» не смогут предпринимать корректирующие действия по отношению к полицейским, что также вызвало сопротивление [41]. Ряд заявителей отказались участвовать в проекте, в том числе из-за нежелания контактировать с офицером полиции, на которого они жаловались [38]. В результате акцент был смещен в сторону неформального разрешения конфликта. В Великобритании набирали популярность согласительные процедуры, и в Австралию для разработки и презентации тренинга по неформальному разрешению конфликтов был приглашен представитель правоохранительных органов Дэнис Мидус [42]. Комиссия сочла, что именно этот метод будет внедрен в практику полицейской работы, так как он «не устанавливает вину и, следовательно, не имеет негативного влияния на карьерные перспективы», а дисциплина будет поддерживаться путем руководства со стороны старшего офицера [38, p. 61].

\section{Метод неформального разрешения конфликта: Квинсленд}

Тренинг в области неформального разрешения конфликта был первоначально проведен для 286 офицеров полиции (которых стали называть уполномоченными членами) со всего штата, а в 1994 г., через семь месяцев работы, программа получила официальную оценку. Комиссия сообщила, что процедура неформального разрешения конфликта была успешно проведена в 345 случаях из общего числа жалоб, составившего 5595 [42]. За то же время медиация, которая также была доступна, проводилась в 95 случаях. Среднее время завершения дела при неформальном разрешении конфликта составило 51 день. Этот показатель был значительно лучше, чем 152 дня при формальном расследовании, однако дела по-прежнему неохотно передавали на неформальное разрешение, и оставалась неясной степень удовлетворенности заявителей результатами процедуры. Мидус провел еще один тренинг и дал ряд рекомендаций, среди которых более активно использовать медиацию. Эту совершенно независимую процедуру он рекомендовал потому, что «для правоохранительных органов было бы предпочтительнее не выступать одновременно в роли органа, ведущего расследование и решающего, достигнуто ли решение по заявлению» [43, p. 48]. Однако медиация не получила дальнейшего развития, хотя комиссия отметила, что «юридический статус медиации позволяет считать ее альтернативой как формальному расследованию, так и неформальному разрешению конфликта или использовать в ситуациях, когда неформальное разрешение конфликта не достигает успеха» [42, p. 3].

Оценка метода неформального разрешения конфликта, проведенная через 12 месяцев его использования, показала, что он был принят в $60 \%$ отделений полиции. Эффективность метода определялась экономией времени при работе с жалобами [44]. Большинство офицеров, прошедших тренинг, сообщали о своей удовлетворенности данным методом. Однако некоторые отмечали, что «испытывают трудности, выполняя согласительные процедуры вместо расследования», и жаловались на большой объем бумажной работы [45, p. XIII]. Мнения о влиянии неформального разрешения конфликтов на взаимоотношения между полицией и сообществом разделились практически поровну. Однако 65 \% выражали сомнения в том, что поведение полицейских изменится. Сообщалось о высокой степени удовлетворенности заявителей, частично благодаря более легкой процедуре доказывания и более широкому выбору вариантов исхода дела по сравнению с методом формального расследования. Однако около 33 \% заявителей сообщили, что на них давили, заставляя выбрать решение, принятое полицией [45]. В целом полицейские были в большей степени удовлетворены процедурой неформального разрешения конфликта по сравнению с формальным расследованием, хотя треть из них посчитали эту процедуру стрессовой [45]. Некоторые сотрудники полиции отметили, что она показала им их ошибки, а конфиденциальность всего процесса позволила им проявить открытость в этом. Другие считали, что таким образом повышается ответственность полицейских за свои действия [45]. У 23 \% заявителей отношение к полиции улучшилось, но 26 \% заявили, что этот опыт «ухудшил их мнение о работе полиции» $[45, \mathrm{p} . \mathrm{XI}]$.

В отчете Комиссии по уголовному правосудию сообщалось, что руководство к проведению проце- 
дуры неформального разрешения конфликта было дополнено рекомендацией проводить медиацию, если заявитель отличается «чувствительным характером» или если присутствует «враждебность» или «непрекращающийся спор», которые могут быть эффективнее урегулированы независимой стороной $[45$, p. 102]. Однако отмечалось также, что полиция считает медиацию слишком затратным методом, нецелесообразным для разрешения мелких конфликтов, а также что она не позволяет обвиняемому полицейскому получить помощь от старших офицеров. В результате дела почти перестали передаваться на процедуру медиации.

\section{Оценка моделей}

Последующая оценка процедуры неформального разрешения конфликта, проведенная в 1996 г., показала снижение уровня удовлетворенности как среди заявителей, так и среди полицейских [40]. Только $6 \%$ дел включали очную встречу заявителя и полицейского, хотя «половина заявителей хотели бы участвовать в очной встрече» [40, p. VI]. Этот показатель не изменился со времени оценки в 1994 г., в результате чего было рекомендовано исключить следующую фразу из полицейского руководства по работе с кадрами: «Предпочтительным методом является неформальное разрешение конфликта без проведения очной встречи/ встреч между заявителем и другими участниками дела» $[40$, p. VI]. Позднейшие изменения утверждали ценность процедуры медиации, если «жалоба не связана с официальными служебными обязанностями полицейского, но в большей степени сходна со спорами между гражданами» [40, p. VII]. И все же медиация продолжает использоваться неактивно.

\section{Управленческое разрешение конфликта: отделение полиции Квинсленда}

В 2000 г., после почти десятилетия господства метода неформального разрешения конфликта, в полиции Квинсленда стали внедрять метод «управленческого разрешения конфликта». При этом согласительная процедура осуществлялась непосредственным начальником обвиняемого полицейского. Процедура включала ряд более серьезных аспектов, которые могли потребовать тренинга или руководства. Пилотный проект под названием Project Resolve проводился в трех полицейских округах. Результаты были сходны с результатами применения метода неформального разрешения конфликта, полученными в 1994 г., включая вывод о недостаточной обученности полицейских, проводящих согласительные процедуры [46].

В 2007 г. Комиссия по преступности и должностным правонарушениям и отделение полиции Квинсленда запустили новую совместную программу по работе с жалобами под названием Project Verity, направленную на передачу мелких жалоб на местный уровень, чтобы сократить дублирование функций Комиссии и отделения полиции в этой области. Позднее результаты проектов Project Resolve и Project Verity были использованы независимыми исследователями при обзоре интегрированной системы работы полиции [46]. В нем отмечалось, что эти проекты укрепили практику внутренних полицейских расследований и оставили акцент на наказании полицейских вместо удовлетворенности заявителя. При этом делался вывод, что следует привлекать больше гражданских лиц к проведению работы с жалобами и «использовать также другие решения, помимо наказаний и укрепления дисциплины, например, более внимательное рассмотрение потребностей заявителя, и принципы восстановительного правосудия» [46, p. 18]. Медиация осталась одним из вариантов разрешения конфликтов, указанных на сайте полиции Квинсленда, однако нет никаких свидетельств о том, что она применялась [47].

\section{Метод управленческого разрешения конфликтов на местном уровне}

В 2018 г. метод «управленческого разрешения конфликтов на местах» заменил как метод неформального разрешения конфликтов, так и метод «управленческого разрешения конфликтов»; цель этого процесса состояла в передаче всей работы с мелкими жалобами на местный уровень. Суть метода состоит в том, что с обвиняемым офицером работает профессиональный менеджер, составляя стратегию предотвращения неподобающего поведения в дальнейшем. При формулировании этой стратегии может быть проведена консультация с заявителем, если это сочтут необходимым, но на практике этого не происходит. В Руководстве по работе с жалобами данный метод определяется как «совокупность приемов управления», включая медиацию [48, раздел 3.2]. Однако на сайте отделения 
полиции в разделе о работе с жалобами медиация не упоминается. Заявителям предлагается форма, где они должны выбрать предпочтительный способ разрешения конфликта - управленческое разрешение конфликта на местном уровне или согласительную процедуру [49]. Участники опроса сообщали, что варианты разрешения конфликта обсуждаются при приеме заявления, но нет никаких данных о том, что медиация запрашивалась или применялась.

\section{Результаты 2:}

\section{Полуструктурированные интервью}

Многие лица, принимавшие участие во внедрении процедур неформального разрешения конфликтов и медиации в Квинсленде, в настоящее время вышли в отставку; они недоступны для опроса или немногое помнят о причинах реформирования системы работы с жалобами после дела Фитцджеральда. Тем не менее на интервью согласились двенадцать бывших и действующих представителей соответствующих органов. Результаты опросов сведены в три группы, соответствующие подразделам ниже: Комиссия по преступности и коррупции (интервью 1-3) [33], отдел по разрешению конфликтов (интервью 4-5) [33] и отделение полиции Квинсленда (интервью 6-7) [34, 35]. Опрошенные из Комиссии по преступности и коррупции - это сотрудники, работающие с 1990-х гг. по настоящее время, с опытом работы 15-20 лет в области урегулирования конфликтов. Опрошенные из отделения по разрешению конфликтов занимали различные должности в системе уголовного правосудия; один из них участвовал в запуске пилотной программы в 1992 г., двое около 5-10 лет занимают должности, связанные с медиацией. Опрошенные из отделения полиции Квинсленда имеют опыт работы 15-20 лет, а опыт работы с жалобами - 2-5 лет.

Анализ данных проводился с помощью объяснительного подхода. Основное внимание уделялось опыту работы, знаниям и мнениям опрашиваемых. Проводились как групповые, так и индивидуальные интервью. Данные, полученные в результате изучения документации и интервью, включая кодировку по темам, анализировались с помощью программы QSR NVivo. Индивидуальным ответам присваивались коды; определялись повторяющиеся темы, такие как вопросы стоимости, управления поведением, внутреннего контроля, конфиденциальности.

\section{Комиссия по преступности и коррупции}

После дела Фитцджеральда перед Комиссией по уголовному правосудию стояла задача проработать поток заявлений на злоупотребление служебным положением и неправомерные действия полиции; это было необходимо осуществить в рамках новой организационной структуры, состоящей из пяти подразделений: отдел по злоупотреблениям служебным положением, трибунал по делам о злоупотреблениях служебным положением, отдел исследований и координации, отдел секретных расследований, отдел защиты свидетелей [12]. Информация была доступна всем отделам Комиссии, хотя в некоторых случаях только по запросу (интервью 7: интервью Комиссии по преступности и коррупции 1-3). Между отделами наблюдалось соперничество, при этом отдел по работе с жалобами противодействовал всяким попыткам «мягкого» решения конфликтов. Этот отдел состоял преимущественно из юристов и старших полицейских (последние на неполную ставку), и ни юристы, ни отделение полиции в целом не поощряло очные встречи между заявителями и обвиняемыми офицерами (интервью 7).

Однако полномочия Комиссии по уголовному правосудию по отношению к отделению полиции Квинсленда были ограничены лишь возможностью давать рекомендации. В Комиссии наблюдался дефицит кадров, и очень скоро она перестала справляться с объемом поступающих жалоб (интервью 9). В тот же период было заявлено, что эффективность системы внутренней дисциплины в отделении полиции Квинсленда повысилась, и было принято решение передавать более мелкие жалобы в отделение полиции (интервью 8). При этом расследования по таким жалобам проводились «столь же тщательно, что и по более серьезным нарушениям, но удовлетворенность заявителей не возрастала» (интервью 7). В результате система работы с жалобами была реформирована в направлении введения альтернативных методов, включая медиацию (интервью 8). При этом в интервью 7 отмечалось, что реформы встретили сопротивление со стороны полиции, «потому что, используя медиацию, вы теряете контроль». Имеется в виду, что стороны процесса, включая независимого медиатора, определяют содержание дискуссии и окончательное решение, тогда как полицейское руководство не может на это повлиять. Как отмечалось в интервью 9, по 
сравнению с процедурой формального расследования, пилотная программа медиации вполне удовлетворяла потребности заявителей в своевременном разрешении конфликта и возможности личного контакта, но ставила перед отделением полиции проблемы финансового и управленческого характера; это подтверждается анализом документации. После дела Фитцджеральда полиция была нацелена на реформирование системы работы с жалобами, но «для реальной оценки эффективности различных подходов» (интервью 7) не было времени. На практике наилучшим подходом для полиции считался метод неформального разрешения конфликтов.

\section{Отдел по разрешению конфликтов: Квинсленд}

Респондент под кодом 12 (интервью 4 отдела по разрешению конфликтов) непосредственно участвовал в пилотной программе медиации в 1992 г. Респонденты 10 и 11 (интервью 5 отдела по разрешению конфликтов) знали о текущей деятельности отдела по разрешению конфликтов и его взаимодействии с отделением полиции Квинсленда, но в отношении прошлой ситуации опирались на данные отчета по пилотной программе медиации жалоб на сотрудников полиции.

Созданный в 1990 г., отдел по разрешению конфликтов первоначально занимался медиацией по заявлениям граждан на граждан, затем медиацией любых конфликтов, в которых не участвовали несовершеннолетние. Кроме того, они готовили медиаторов, некоторые из них участвовали в пилотной программе медиации в рамках программы «Правосудие на местах». Отдел также вел активную деятельность по внедрению институциональных изменений в государственных организациях, вводя альтернативные процедуры разрешения конфликтов (интервью 11). После успеха пилотной программы медиации отдел работал совместно с отделением полиции Квинсленда по внедрению стратегий медиаций при работе с жалобами граждан. Частью процесса было присутствие полицейского на медиации без униформы (респондент 12) - вероятно, для достижения равенства и минимизации дисбаланса сил, что является одной из задач медиации. Однако затем отделение полиции Квинсленда переключилось на процедуры внутреннего расследования и согласительные процедуры, и ме- диация вышла из употребления. Некоторые респонденты выражали удивление по этому поводу, «ведь согласительные процедуры отличаются недостатком непредвзятости» (респонденты 10 и 11). Они могли припомнить только один случай, когда отделение полиции Квинсленда «запросило процедуру реституционного правосудия» при работе с заявлением, которая закончилась безрезультатно по неизвестной причине (респондент 10).

В 2015 г. отдел по разрешению конфликтов вновь инициировал переговоры с отделением полиции Квинсленда по поводу объема процедур реституционного правосудия в ответ на жалобы граждан. По словам респондента 10, «в то время с начальником отдела полиции можно было это обсуждать», но затем произошли перестановки в руководстве, и переговоры не привели к какому-либо результату. Тем не менее после многих лет тесного сотрудничества с полицией респондент считал, что система работы с жалобами неэффективна, многие кадровые офицеры чувствовали ее несправедливость (респондент 10). Им не нравилось, что благодаря характеру их работы граждане могут жаловаться, а механизм разрешения конфликта не дает им «той же степени защиты или идеи о презумпции невиновности, которой пользуются граждане у себя на рабочих местах» (интервью 10). Полицейские расценивали эту ситуацию как двойные стандарты, считали, что не могут защитить себя. По словам одного из респондентов, «большинство полицейских, с которыми я общался, хотели бы иметь какую-то иную модель работы с жалобами граждан» (интервью 10).

Недавно в отделении полиции Квинсленда были запущены тренинги по медиации по разрешению конфликтов на рабочем месте. Респонденты отметили, что участвующие в них полицейские крайне довольны этой моделью; они считают ее справедливой и доверяют ей в первую очередь благодаря фактору независимости. Поскольку медиация является основным компонентом реституционного правосудия, отдел по разрешению конфликтов утверждает, что «модель реституционного опроса» позволит полиции «сделать выводы и извлечь уроки из инцидента, при этом никого не стигматизируя» (интервью 11). Предполагается, что применение реституционных практик в повседневном взаимодействии полиции и граждан позволит затем перейти к внедрению модели рести- 
туционного опроса в рамках медиации. Это потребует значительного культурного сдвига, но в отделе по разрешению конфликтов считают, что большинство офицеров полиции «положительно воспримут новую модель, основанную на принципах реституционного правосудия» (интервью 10). Также отмечается, что отдел по разрешению конфликтов не возражает против запуска программы медиации для разрешения конфликтов между полицейскими и гражданскими лицами.

\section{Отделение полиции Квинсленда}

В интервью с сотрудниками отделения полиции Квинсленда (интервью 5 и 6) были обозначены следующие проблемы при использовании независимой медиации для разрешения конфликтов между полицейскими и гражданскими лицами; намечены также направления будущей работы в этой области.

\section{Материальные и временные затраты}

Сотрудники отделения полиции Квинсленда высказывали сомнения в эффективности медиации в аспекте ее материальных затрат, включая выделение ресурсов, оплаты процедуры медиации, а также временных затрат, в том числе выделение времени для сессий и разъяснение процедуры заявителям. Поскольку большинство жалоб касается мелких нарушений, в отделении полиции Квинсленда считают нецелесообразным отрывать полицейских от их обязанностей для проведения процедуры медиации. Затраты на проведение сессий было бы предпочтительнее направить на оперативную работу. Сессия может происходить спустя несколько недель после инцидента, что негативно скажется на «достаточно плотном рабочем расписании сотрудников» (интервью 1). Кроме того, ряд опрошенных сотрудников отделения полиции Квинсленда сообщили, что, по их опыту, многие заявители «остывают» еще до первой встречи по поводу их жалоб (интервью 2 и 4). Таким образом, исчезает необходимость назначать процедуру медиации.

\section{Конфиденциальность}

Утверждается, что конфиденциальность медиации приводит к ряду проблем в работе полиции. Во-первых, отделение полиции получает очень мало информации, чтобы решить, следует ли наказать обвиняемого полицейского, понаблюдать за ним или отправить на переподготовку. Во-вторых, существует опасение, что на процедуре медиации полицейские могут признаваться в том, чего не совершали, а гарантии конфиденциальности такой информации нет. В-третьих, в полиции опасаются, что медиация может использоваться некоторыми заявителями как возможность выливать свои проблемы и обвинять полицейских. Отделение полиции вполне справедливо хочет защитить своих сотрудников от личных нападок. Однако опрошенные сообщили только о двух случаях, когда рассматривалась возможность применения медиации. В одном случае заявительница не соглашалась подписывать решение, пока не встретится с обвиняемым офицером лично и не услышит его извинений. Отделение полиции отклонило это требование, считая, что заявительница может использовать эту возможность, чтобы оскорблять полицейского. Было отклонено также участие подготовленного независимого медиатора, так как предполагается, что участие сторон в процедуре медиации должно быть строго добровольным. Во втором случае речь шла о незначительном нарушении; процедура была проведена сотрудником полиции и закончилась положительным результатом.

\section{Различные типы заявителей}

Отделение полиции Квинсленда отличается разнообразным по возрасту и культурному уровню составом персонала и обслуживает настолько же разнообразное население. Реакция представителей разных поколений при взаимодействии может быть неоднозначной и приводить к конфликтам. По мнению полиции, медиация подходит представителям одних поколений и не подходит другим, хотя специально этот вопрос не исследовался. В отношении культурных различий было проведено сравнение с ситуацией в США. Было высказано мнение, что «серьезные проблемы с доверием внутри сообщества», наблюдающиеся во многих американских штатах, не характерны для Австралии (интервью 1). Легалистический подход к такого рода заявлениям (т. е. мгновенное «сплочение» полицейских) может вести к использованию медиации в целях недопущения эскалации, например, массовых беспорядков. Австралийская полиция не сталкивается с такого рода конфликтами (интервью 1). 


\section{Противодействие независимой медиации}

Опрошенные сотрудники отделения полиции Квинсленда утверждали, что пилотный проект по использованию медиации в 1990-е гг. «проводился в организации, неготовой к диалогу с заявителем, поэтому медиация была положительным опытом» (интервью 1). Однако последовательные реформы системы работы с жалобами, включая внедрение Проекта реформирования работы с жалобами в 2018 г., запустили открытый диалог между сообществом и отделением полиции. В настоящее время в рамках указанного проекта заявления должны проходить оценку внутреннего комитета, рассортировываться и затем рассматриваться одним из 23 профессиональных менеджеров. Таким образом, по мнению отделения полиции, сейчас работа с жалобами налажена хорошо. Медиация входит в число доступных опций, но опрошенные не смогли ничего рассказать о ее применении. Как сказал респондент 2 , если бы она [медиация] была наилучшим методом, то применялась бы чаще всего. Естественным образом ее выбирали бы чаще. Поскольку это не так, значит, отделение полиции видит в ней больше недостатков.

Отделение полиции не возражает против использования внешних медиаторов из числа гражданских лиц, если они обладают достаточной квалификацией, однако предпочитает «медиатора из числа штатных сотрудников при сохранении возможности пригласить независимого специалиста, если это необходимо» (интервью 4).

По-прежнему считается, что для более серьезных жалоб на любой стадии расследования процедура медиации не подходит. По закону отделение полиции обязано сообщать о серьезных нарушениях дисциплины в Комиссию по преступности и коррупции, где рассматривается вопрос о возможности дальнейшей службы обвиняемого в полиции. По мнению сотрудников отделения полиции, «они не заинтересованы в проведении медиации. Их не устраивает ее результат» (интервью 1).

\section{Полномочия}

По мнению опрошенных, за последние 30 лет обстановка в правоохранительной сфере кардинально изменилась. Благодаря механизмам подотчетности появилась процессуальная и правовая прозрачность, особенно в отношении работы с жалобами (интервью 3). Комиссия по преступности и коррупции наделяет отделение полиции полномочиями для расследования неподобающего поведения, наложения дисциплинарных санкций и увольнения офицеров полиции, а также для любых видов работы с заявлениями (интервью 1). Эти полномочия были закреплены в 2018 г. после введения Упрощенной дисциплинарной процедуры (Abridged Disciplinary Process, ADP), которая дала возможность быстро расследовать мелкие нарушения. Если обвиняемый полицейский признает свое нарушение, то дело быстро закрывается. Заявителю направляется письменное уведомление, а Комиссия по преступности и коррупции отказывается от своего права на контролирующие функции (интервью 7). В Комиссии считают, что отделение полиции «слишком глубоко занимается $A D P »$ » чтобы рассматривать медиацию в качестве альтернативы, а дальнейшие изменения в законодательстве «закрепят преимущества» данной процедуры и сведут на нет необходимость в медиации (интервью 7). Кроме того, согласно недавним опросам, степень удовлетворенности общественности профессионализмом полиции очень высока (87 \%), что подтверждает доверие граждан к полиции.

\section{Реституционное правосудие}

Как упоминалось ранее, в отделении полиции Квинсленда проводился тренинг с участием внешних специалистов, посвященный медиации конфликтов на рабочем месте. Недавно был запущен проект Juniper, нацеленный на противодействие травле, преследованиям, и тренинг устойчивости к внешним воздействиям. По словам одного из опрошенных, это «большой пласт работы (...) [и] мы движемся к применению подходов реституционного правосудия и медиации во внутренних делах» (интервью 1). В отделах полиции Квинсленда работают команды консультантов, в том числе внешние медиаторы; цель этих программ внедрение медиации в качестве «лучшей практики». При этом использование этого метода для разрешения внешних конфликтов не планируется.

\section{Обсуждение}

Результаты настоящего исследования показывают, что система работы с жалобами в полиции Квинсленда прошла долгий путь непрерывного реформирова- 
ния, направленного на совершенствование процесса разрешения конфликта в интересах граждан. При этом, к сожалению, выводы из оценки модели неформального разрешения конфликта и пилотного проекта по медиации лишь усложнили процедуру внутренней работы с жалобами, вместо того чтобы сделать систему более простой и прозрачной. Дополнительные уровни управленческого персонала по-прежнему нацелены на выявление и предотвращение неподобающего поведения среди полицейских и укрепление их дисциплины. Недавние изменения в дисциплинарных процедурах (включая $A D P$ ) отражают стремление отдела полиции улучшить и модернизировать систему. Новая дисциплинарная система использует коррективный подход к случаям неподобающего поведения среди полицейских, применяя «стратегию профессионального развития... будь то ответ на поступившее заявление, в качестве стратегии по смягчению последствий рисков, для исправления поведения полицейского или для любой другой цели» [50]. Однако наше исследование показывает также, что следует уделять больше внимания «потребностям» граждан-заявителей в процессе расследования по их жалобам.

Как было показано, медиация обычно используется в ситуациях, когда действия полиции не предусматривают дисциплинарных или судебных мер. Однако отдел полиции Квинсленда, по всей видимости, ошибочно считает медиацию альтернативной дисциплинарной процедурой, что показывает фраза «если разрешение конфликта достигнуто, в чем смысл медиации?» [33]. Нацеленность на карательные меры против сотрудников полиции говорит о том, что игнорируется важнейший элемент работы с жалобами - воспитательный и восстановительный аспект ситуации после разрешения конфликта, в равной степени для заявителей и для полиции. Кроме того, результаты медиации могут использоваться при планировании мер по совершенствованию деятельности полицейских и организационных изменений в аспекте общей политики и процессов.

Исследование показало, что заявители стремятся к очным встречам с обвиняемыми; они хотят озвучить свои претензии в безопасном окружении, хотят получить объяснения и, возможно, извинения $[6,25$, $5,7]$. Отдел полиции Квинсленда сообщает о 87\%ном уровне удовлетворенности заявителей «про- фессионализмом полиции», но, по другим данным, 75 \% граждан считают, что «полицейские относятся к людям равноправно и справедливо» [9, p. 6.16]. Это означает, что 25 \% опрошенных недовольны отношением полиции, возможно, из-за участия в конфликте с полицейским. Предложение организовать площадку для обсуждения дальнейшего развития внутренних согласительных процедур не встретило поддержки отдела полиции Квинсленда.

Среди других причин отказа отдела полиции Квинсленда от введения процедуры медиации назывались: высокая стоимость, большие затраты времени, конфиденциальность, различные типы заявителей. Услуги медиации требуют оплаты и времени для организации сессий. Кроме того, следует учитывать затраты на расследование по заявлению, связь с заявителем, тренинги для персонала по медиации. В научной литературе было показано, что независимая медиация требует меньше финансовых и временных затрат, чем процедура формального расследования [18-20]. Однако найти сопоставимые данные по сравнению процедуры неформального разрешения конфликта и медиации сложно. Тем не менее, учитывая все возрастающую сложность процедуры неформального разрешения конфликта, медиация, проводимая квалифицированным независимым медиатором, может быть менее затратной, чем ныне действующие согласительные процедуры. Существуют международные программы, финансируемые муниципалитетами (например, Денвера и Нью-Йорка), есть медиаторы, работающие на общественных началах. Влияние этих двух причин [финансовых и временных затрат. - Прим. пер.] в Квинсленде требует особого изучения. Следующий аргумент - что конфиденциальный характер медиации не позволяет отделу полиции собирать данные, необходимые для обучения сотрудников, а также может привести к неверным кадровым решениям или к оскорблениям полицейских заявителями. Этот аргумент опровергается исследователями: «Это ошибка, причина которой в непонимании, что такое медиация и как она работает» [20, р. 1]. В том же исследовании дается рекомендация информировать стороны «о возможных результатах до того, как они примут участие в процедуре медиации» [20, р. 25]. Медиация, включая техники, основанные на принципах реституционного правосудия, нацелена на восстановление 
отношений, нарушенных в результате конфликта. В этом она сходна с процедурой переключения, когда участники не подвергаются наказанию, а получают возможность научиться чему-то новому. Как показали Schulenberg и соавт. [17], многие граждане оценивают систему работы полиции с жалобами как пристрастную, а подачу заявлений считают бессмысленной. Избегание конфронтации может приводить к эскалации конфликта и подрывать доверие граждан к правоохранительным органам. Наконец, последний аргумент состоит в том, что медиация не нужна, так как в Австралии полиция не сталкивается с таким высоким уровнем расовых конфликтов, как в США; однако здесь не учитываются бедные и маргинальные слои населения Австралии, которые часто привлекают внимание полиции, такие как национальные меньшинства и коренные австралийцы. Медиация могла бы помочь снизить количество задержаний и высокое число коренных австралийцев среди заключенных.

Таким образом, в позиции отдела полиции Квинсленда относительно «контроля» за урегулированием мелких жалоб граждан наблюдается нежелание вводить процедуры независимой медиации, передачи полномочий и реституционного правосудия. Однако, как представляется, такая позиция в большей степени объясняется исторически сложившимися барьерами к применению медиации, чем преимуществами согласительных процедур, о которых говорили опрошенные. Как утверждают Walker и соавт. [20], основными барьерами к внедрению и успешному применению медиации являются: недостаток поддержки руководства, опасения руководителей потерять контроль над процессом, недостаток стимулов для заявителей и полицейских для участия в процедуре медиации. В отделе полиции Квинсленда развивают новую модель «управленческого разрешения конфликтов на местах», что свидетельствует о поддержке руководством процедур внутреннего расследования, сохраняющих уровень контроля полиции над процессом. Однако при этом предполагается, что соглашения, достигнутые в результате медиации, исключают любые дальнейшие действия полицейского руководства относительно поведения сотрудника, участвовавшего в медиации, а это совершенно не обязательно. Некоторые жалобы против полицейских не подходят для процедуры медиации (например, когда заявитель не является предполагаемой жертвой), но они могут также не подходить для неформальных (согласительных) процедур, а требовать формального расследования. Таким образом, нет препятствий к тому, чтобы жалобы на незначительные нарушения рассматривались с помощью независимой процедуры, дающей возможность заявителю высказать свою точку зрения.

В других юрисдикциях, например в Денвере и Лос-Анджелесе, эту проблему решают через сотрудничество с внешними профессиональными организациями в области медиации; независимая медиация при работе с жалобами интегрируется в практику при поддержке руководства $[51,24]$. В такой модели медиация выступает ключевым вариантом при рассмотрении возможных ответов на заявление [2]. При научном подходе к деятельности полиции такая преимущественная роль медиации потребует работы соответствующих специалистов в штате надзорного органа или государственного или частного агентства по медиации. В случае такого географически обширного штата, как Квинсленд, крупномасштабная общедоступная программа медиации может быть реализована путем создания государственной интегрированной комиссии, обслуживающей всю правоохранительную систему, с сетью региональных представительств [2, p. 14].

\section{Заключение}

За последние три десятилетия система работы с жалобами полиции Квинсленда непрерывно подвергалась изменениям. В результате проведения нескольких пилотных проектов по альтернативному разрешению конфликтов, включая медиацию, в практику работы были внедрены «лучшие практики». Однако доминирующим подходом с переменной популярностью оставался согласительный подход. Изучение истории вопроса показало картину развития системы работы с жалобами и обоснований необходимости реформ. Отдел полиции Квинсленда продолжает считать, что авторитет полиции, знание законов, которым она обладает, исключает их из круга лиц, которым медиация необходима для разрешения возникающих проблем. Однако такая точка зрения представляется односторонней, она не учитывает потребностей заявителей и их ожиданий от медиации, выявленных в ходе эмпирического исследования. Внедрение процедуры неформального разрешения конфликтов или 
согласительных процедур было призвано снизить «игнорирование заявителей, происходившее в случае полного расследования <...> но это не помогло» [52, p. 108]. Подобная ситуация повторяется сегодня. В Квинсленде заявители по большей части исключены из процесса расследования по их заявлениям. Они получают извещение о результатах расследования, что может включать извинение, но у них нет возможности напрямую высказать, как на них повлиял инцидент, или получить ответ на вопрос, почему полицейский действовал так, а не иначе.

Медиация как опция при работе с жалобами существует в рамках полицейских процедур, но степень, до которой она раскрывается заявителям, трудно определить. Все же, несмотря на нежелание использовать медиацию для разрешения конфликтов с гражданами, отдел полиции Квинсленда применяет ее для разрешения внутренних конфликтов, поэтому можно предположить, что значимость независимой медиации как инструмента урегулирования конфликтов будет постепенно осознаваться правоохранительными органами. Представляется, что сложности с внедрением медиации для разрешения конфликтов между гражданами и полицией объясняются недостатком исследований по оценке существующих программ. Имеющиеся оценки очень старые и относятся к юрисдикциям, значительно отличающимся от Австралии в культурном, экономическом и политическом плане, поэтому их результаты не следует обобщать. Для оценки факторов, влияющих на эффективность таких программ, необходимы новые исследования. Тем не менее неоспоримым остается тот факт, что заявители рассматривают медиацию как возможность повлиять на ход расследования по своей жалобе.

Доверие сообщества к правоохранительным органам является обязательным условием их способности выполнять свои функции, а система работы с жалобами - неотъемлемый элемент такого доверия. Как указывает Goldsmith, «механизмы подотчетности полиции [т. е. системы работы с жалобами] абсолютно необходимы для обеспечения принятия роли полиции со стороны общества» [1, p. 36]. Настоящее исследование позволяет сделать вывод, что удовлетворенность граждан работой правоохранительных органов невозможно повысить путем бесконечных реформ, в ходе которых недостатки в деятельности полиции расследуются самой полицией. Это можно сделать, только расследуя жалобы альтернативными методами разрешения конфликтов, включая независимую медиацию, в интересах заявителей.

Отдел полиции Квинсленда определил своей задачей «поддерживать высокий уровень удовлетворенности граждан и доверия к правоохранительным органам в условиях меняющейся реальности» [32, p. 13]. Работа с жалобами является составной частью этой задачи, и, по опыту других юрисдикций, внутренние согласительные процедуры уже не отвечают запросам общества на высокую степень прозрачности, непредвзятости, равенства, экономической и временной эффективности процедур и требованиям новых форматов поведения сотрудников правоохранительных органов.

\section{Список литературы / References}

1. Goldsmith A. J. Informal resolution of police complaints in Australia: Building better understanding or mere bureaucratic convenience, Law in Context, 2000, No. 17 (1), pp. 34-58.

2. Riley M., Prenzler T., McKillop N. Alternative dispute resolution and mediation of complaints against police in Australia and New Zealand, Police Practice and Research, International Journal, 2018, No. 1-15. DOI: https://doi.org/10.1080/15614263 .2018 .1500284

3. Australian Law Reform Commission, Police accountability, 2018, Summary No. 14.49, available at: https://www.alrc.gov. $\mathrm{au} /$ publication/pathways-to-justice-inquiry-into-the-incarceration-rate-of-aboriginal-and-torres-strait-islander-peoples-alrc-report133/14-police-accountability/complaints-against-police/

4. Ede A. Barnes M. Making the response fit the complaint: Alternative strategies for resolving complaints against police, Research \& Issues Paper, Series 1, 2002, available at: https://www.ccc.qld.gov.au/sites/default/files/Docs/Publications/CMC/ Bulletins\%2Cseries-and- discussion-papers/Research-and-issues-paper- series/Research-and-Issues-Making-the- response-fit-thecomplaint-2002.pdf

5. Schaible L. M., DeAngelis J., WolfB., Rosenthal R. Denver's citizen/police complaint mediation program: Officer and complainant satisfaction, Criminal Justice Policy Review, 2012, No. 24 (5), pp. 626-650. DOI: https://doi.org/10.1177/0887403412455327 
6. Bartels E. C., Silverman E. B. An exploratory study of the New York City Civilian Complaint Review Board mediation program, International Journal of Police Strategies and Management, 2005, No. 28 (4), pp. 619-630. DOI: https://doi. org/10.1108/13639510510628703

7. Young R., Hoyle C., Cooper K., Hill R. Informal resolution of the complaints against the police: A quasi-experimental test of restorative justice, Criminal Justice, 2005, No. 5 (3), pp. 279-317. DOI: https://doi.org/10.1177/14668025050558377

8. Maguire M., Corbett C. A study of the police complaints system, Her Majesty's Stationary Office, 1991.

9. Productivity Commission. Report on government services (Chapter 6, Police Services, 6.16), Australian Government Productivity Commission, 2018, available at: https://www.pc.gov.au/research/...government.../police.../rogs-2018-partc-chapter6.pdf

10. Prenzler T. Police corruption: Preventing misconduct and maintaining integrity, CRC Press/Taylor \& Francis, 2009.

11. Crime and Misconduct Commission, Handling complaints against Queensland police: past, present and future, 2004, August, No. 2, available at: https:/www.ccc.qld.gov.au/sites/default/files/Docs/Publications/CMC/Bulletins\%2Cseries-and-discussionpapers/Monitoring-integritv-in-the-queensland-police-service/Handling-complaints-against-qld-police-Report-2004.pdf

12. Fitzgerald G. E. Commission of inquiry into possible illegal activities and associated police misconduct, Queensland, Crime and Corruption Commission, 1989, available at: https://www.ccc.qld.gov.au/sites/default/files/Docs/Publications/CCC/ The-Fitzgerald-Inquiry-Report-1989.pdf

13. Sunshine J., Tyler T. R. The role of procedural justice in shaping public support for policing, Law \& Society Review, 2003, No. 37, pp. 513-548. DOI: https://doi.org/10.1111/1540-5893.3703002

14. Wells W., Schafer J. A. Police scepticism of citizen oversight: Officers' attitudes toward specific functions, processes, and outcomes, Journal of Crime and Justice, 2007, No. 30 (20), pp. 1-25. DOI: https://doi.org/10.1080/0735648X.2007.9721233

15. De Angelis J., Kupchik A. Citizen oversight, procedural justice, and officer perceptions of the complaint investigation process, International Journal of Police Strategies \& Management, 2007, No. 30 (4), pp. 656-671. DOI: https://doi. org/10.1108/13639510710833929

16. Queensland Police Service, Complaints management policy, 2016, May 24, QPS Headquarters, Brisbane, Queensland: Queensland Police Service.

17. Schulenberg J. L., Chenier A., Buffone S., Wojciechowski C. An application of procedural justice to stakeholder perspectives: Examining police legitimacy and public trust in police complaints systems, Policing and Society, 2015, No. 1-16. DOI: https:// doi.org/10.1080/10439463.2015.1102252

18. Goldsmith A. J. Complaints against the police: A 'community policing' perspective, In S. McKillop, J. Vernon (eds.), The police and the community in the 1990s: Conference proceedings, 1990 (pp. 205-218), Australian Institute of Criminology, Canberra.

19. Holland R. C. Dealing with complaints against the police: The resolution process adopted by the Queensland Police Service, Australia, Police Studies, 1996, No. 19 (2), pp. 45-62. DOI: https://doi.org/10.1108/13639519610123172

20. Walker S., Archbold C., Herbst L. Mediating citizen complaints against police officers: A guide for police and community leaders. U.S. Department of Justice, Office of Community Oriented Policing Services, 2002, available at: http://restorativeiustice. org/am- site/media/mediating-citizen-complaints-against-police-officers.pdf

21. Hill R., Cooper K., Young R. P., Hoyle C. Meeting expectations: The application of restorative justice to the police complaint process, Oxford University Centre for Criminological Research, 2003.

22. Waters I., Brown K. Police complaints and the complainants' experience, British Journal of Criminology, 2000, No. 40 (4), pp. 617-638. DOI: https://doi.org/10.1093/bic/40.4.617

23. Proctor J. L., Rosenthal R., Clemmons A. J. Denver's citizen/police complaint mediation program: A comprehensive evaluation, 2008.

24. Office of the Independent Police Monitor, City of New Orleans. Community-police mediation program: annual report, 2018, available at: http://nolaipm. gov/annual-reports/.

25. Holmberg L. In service of the truth? An evaluation of the Danish Independent Police Complaints Authority, European Journal of Criminology, 2019, No. 1-20. DOI: https://doi.org/10.1177/1477370819856514

26. Australian Bureau of Statistics, 1992 year book, available at: https://www.ausstats.abs.gov.au/ausstats/free.nsf/0/2415DA D15B7F1E7FCA257AFE001471C4/\$File/13013\%20-Qld\%20YrBook\%20-\%201992.pdf

27. Australian Bureau of Statistics. Queensland population (1387.3 - Queensland in review, 2003), available at: https://www. abs.gov.au/Ausstats/abs@.nsf/Lookup/CF3424B58ECB69C8CA256CC500211FCA

28. Criminal Justice Commission, 1991-1992 annual report of the Criminal Justice Commission, 1992, available at: https:// www.ccc.qld.gov.au/publications/cic-annual-report-1991-1992

29. Queensland Government Statistician's Office, Queensland population, 2020, available at: https://www.qgso.qld.gov.au/ statistics/theme/population/population-estimates/state-territories/qld- population-counter

Райли М., Пренилер Т. Согласительные процчедуры или медиация: работа с жалобами на действия полищии в австралийском итате Квинсленд Riley M., Prenzler T. Conciliation Versus Mediation of Complaints Against Police: Lessons from the Queensland Experience 
30. Productivity Commission. Report on government services (Chapter 6: Police Services, 6.3), Australian Government Productivity Commission, 2019, available at: https://www.pc.gov.au/research/ongoing/report-on-government-services/2019/iustice/ police-services

31. Geoscience Australia, Area of Australia - states and territories, Australian Government, 2020, available at: https://www. ga.gov.au/scientific-topics/national-location-information/dimensions/area-of-australia-states-and-territories

32. Queensland Police Service, 2018-2019 annual report of the Queensland Police Service, 2019, available at: https://www. police.qld.gov.au/index.php/qps- corporate-documents/reports-and- publications/annual-report-2018-2019.

33. Queensland Police Service, 2018, November 26 - Interviewees 1-4, Semi-structured interviews, QPS Headquarters, Brisbane, Queensland; 2019, July 27 - Interviewee 5, Semi-structured interview, Maroochydore, Queensland.

34. Hampshire Police Service. (2019, January 9 - Interviewee 6), Semi-structured interview (telephone), London, England.

35. Crime and Corruption Commission. (2018, June 14, 28 and July 11 - Interviewees 7-9). Semistructured interview (telephone and in person), Brisbane, Queensland.

36. Dispute Resolution Branch. (2018, November 7 - Interviewees 10-11). Semi-structured interview, Brisbane, Queensland: Department of Justice and Attorney General.

37. Dispute Resolution Branch. (2019, June 24 - Interviewee 12). Semi-structured interview (email).

38. Criminal Justice Commission, 1992-1993 annual report of the Criminal Justice Commission (Mediation - Appendix 1, and Informal resolution - Appendix 2), 1993, available at: http://www.ccc.qld.gov.au/research-and- publications/research-andpublications-1

39. Criminal Justice Commission, Report on the pilot project for the mediation of complaints against police (February - August 1992), Legal Office, Criminal Justice Commission, Brisbane, Queensland, 1992.

40. Criminal Justice Commission, Informal complaint resolution in the Queensland Police Service: Follow-up evaluation (April 1996), Brisbane, Queensland, Criminal Justice Commission, Research and Co-ordination Division, 1996.

41. Crime and Corruption Commission (CCC), Accountability and leadership, 2019, available at: http://www.ccc.qld.gov.au/ about-the-ccc/accountability-and-leadership/accountability-and-leadership

42. Criminal Justice Commission, Informal complaint resolution in the Queensland Police Service: A progress report (February, 1994), Brisbane, Queensland, Criminal Justice Commission, Research and Co-ordination Division, 1994, pp. 1-14.

43. Meadus D. Complaints against police officers in the Commonwealth of Australia, Hampshire Constabulary, 1988.

44. Criminal Justice Commission, 1993-1994 annual report of the Criminal Justice Commission, Processing of complaints, 1994, available at: http://www.ccc.qld.gov.au/research-and- publications/research-and-publications-1

45. Criminal Justice Commission, Informal complaint resolution in the Queensland Police Service: An evaluation (November, 1994), Brisbane, Queensland, Criminal Justice Commission, Research and Co-ordination Division, 1994.

46. Webbe S., Williams G., Grayson F. Simple effective transparent strong: An independent review of the Queensland Police complaints, discipline and misconduct system, Department of the Premier and Cabinet, Queensland Government, Independent Expert Panel, 2011, available at: https://cabinet.qld.gov.au/documents/2011/May/Police\%20Discipline\%20Review/Attachments/ independent-review-of-qld-police-discipline-system.pdf

47. Crime and Misconduct Commission, Setting the standard: A review of current processes for the management of police discipline and misconduct matters, 2010, December, available at: https://www.ccc.qld.gov.au/sites/default/files/Docs/Publications/ CMC/Setting-the-standard-2010.pdf

48. Queensland Police Service, Complaint resolution guidelines (Local Management Resolution Policy and Local Management Resolution Strategies - s. 3.2 General Information), QPS Headquarters, Brisbane, Queensland, Queensland Police Service, 2018.

49. Queensland Police Service, Compliments and complaints, 2018, available at: https://www.police.qld.gov.au/online/Complime ntsandComplaints.htm

50. Police Service Administration (Discipline Reform) and Other Legislation Amendment Bill, 2019, p. 4, available at: https:// www.legislation.qld.gov.au/view/pdf/asmade/act-2019-032

51. Los Angeles Police Department, 2017 annual report of the Los Angeles Police Department, 2018, available at: http://assets. lapdonline.org/assets/pdf/2017\%20 Q4\%20BP.pdf

52. Meadus D. Informal resolution, In K. Bryett, C. Lewis (eds.), Un-peeling tradition: Contemporary policing (pp. 107-122), Macmillan Education Australia, 1994.

53. Office of the Independent Police Monitor, Denver, 2007 annual report, Denver, Colorado, Office of the Independent Police Monitor, 2007.

54. Queensland Police Service, Policing Queensland timeline 1864-2014, 2020, available at: https://www.police.qld.gov.au/ queensland-police-museum/policing-queensland-timeline-1864-2014

Райли М., Пренилер Т. Согласительные процедуры или медиация: работа с жалобами на действия полиции в австралийском штате Квинсленд Riley M., Prenzler T. Conciliation Versus Mediation of Complaints Against Police: Lessons from the Queensland Experience 
55. Queensland Government, Diversity figures snapshot, Census 2016, 2020, available at: https://www.dlgrma.qld.gov.au/ resources/multic ultural/communities/diversity-flyer.pdf

56. Riley M., Prenzler T. Conciliation Versus Mediation of Complaints Against Police: Lessons from the Queensland Experience, Criminology, Criminal Justice, Law \& Society, 2020, Vol. 21, No. 1, pp. 22-38.

Дата поступления / Received 16.09.2020

Дата принятия в печать / Accepted 20.10.2020

Дата онлайн-размещения / Available online 25.12.2020

(C) Райли М., Пренцлер Т.2 , 2020. Впервые опубликовано на русском языке

в журнале «Актуальные проблемы экономики и права» (http://apel.ieml.ru) 25.12.2020

(C) Riley M., Prenzler T. ${ }^{3}, 2020$

\footnotetext{
2 Мэри Райли является преподавателем Школы права и криминологии, университет Саншайн-Кост, г. Сиппи Даунс, Австралия, с 2012 г. Ранее она занимала руководящие должности в банковской сфере и здравоохранении, работала помощником юриста в юридических компаниях в штатах Новый Южный Уэльс и Квинсленд. Она окончила университет Саншайн-Кост и получила степень магистра криминологии и уголовного правосудия с отличием в университете Гриффита. Область ее научных интересов - реституционное правосудие. В настоящее время она работает над кандидатской диссертацией, рассматривая преимущества медиации и других альтернативных методов разрешения конфликтов при разборе жалоб против полиции в Австралии. Ранее опубликованные работы были посвящены альтернативным методам разрешения конфликтов и реабилитации правонарушителей. Также Мэри Райли разработала и ведет курсы по реституционному правосудию, медиации, методам наказания и коррекции, правовой системе Австралии, проблемам преступности и убийств.

Тимоти Пренцлер работает профессором в области криминологии и правосудия Школы права и криминологии, университет Саншайн-Кост, г. Сиппи Даунс, Австралия, с 2015 г., когда стал координатором программы подготовки бакалавров в этой сфере. Ранее он являлся одним из основателей Школы криминологии и уголовного правосудия в университете Гриффита, основанной в 1991 г., где он занимал позиции координатора различных программ и возглавлял Школу с 2003 по 2005 г. Также в университете Гриффита он был одним из основателей Австралийского научного консультационного центра по совершенствованию правоохранительной деятельности и безопасности, где с 2008 по 2014 г. координировал Программу систем интеграции. Научные интересы включают профилактику преступности и коррупции, безопасность сотрудников полиции и служб охраны, регулирование деятельности охранных организаций, гендерное равенство в полиции. Опубликовал более 100 статей в научных журналах и 60 глав в книгах. Разработал и ведет курсы по основам криминологии, правоохранительной деятельности, профилактике преступности, этике и подотчетности уголовного правосудия.

3 Mary Riley is a Lecturer in the School of Law and Criminology, at USC Australia, Sippy Downs. Mary joined USC in 2012 after working in managerial positions in the banking and health industries and para-legal positions in NSW and Queensland law firms throughout her life. Mary is a graduate of USC and received a Master of Criminology and Criminal Justice with Class 1 Honours through Griffith University. Mary's area of interest and research is restorative justice. She is undertaking a PhD looking specifically at the benefits of mediation and other alternative dispute resolution processes for managing complaints against police in Australia. Mary has previously published research on alternative dispute resolution and in the field of offender rehabilitation. She has developed and taught courses in restorative justice and mediation, punishment and corrections, justice and the Australian legal system, understanding crime and homicide.

Timothy Prenzler is a Professor of Criminology \& Justice in the School of Law and Criminology, at USC Australia, Sippy Downs. Tim joined USC in 2015 as the inaugural Program Coordinator of the Bachelor of Criminology and Justice. He was previously a foundation member of the School of Criminology and Criminal Justice at Griffith University, established in 1991, where he held numerous Program Coordinator positions and was Head of School from 2003 to 2005. At Griffith, he was a foundation member of the Australian Research Council Centre of Excellence in Policing and Security, where he was Coordinator of the Integrity Systems Program from 2008 to 2014. His research interests include crime and corruption prevention, police and security officer safety, security industry regulation, and gender equity in policing. Tim has published over 100 journal articles and 60 book chapters. He has developed and taught courses in introductory criminology, policing, crime prevention, and criminal justice ethics and accountability.
} 